\title{
Tolerance Effect of Some Sugarbeet Varieties to Root Knot Nematode, Meloidogyne incognita and Efficacy of Nemacur (Fenamiphos) Control under Field Conditions
}

\author{
Gohar, I.M.A; ${ }^{1}$ A.A. Abo El-Ftooh ${ }^{1}$ M. S. Saleh ${ }^{2}$ and Mohamed, Kh. El-Sh ${ }^{3}$ \\ ABSTRACT \\ yield, sugar recovery and ultimately gave maximum sugar \\ yield under some nematode control measures.
}

To find out the level of susceptibility of certain sugarbeet varieties to Meloidogyne incognita. Also to determine the combined effect of Meloidogyne incognita on the growth and yield components of different varieties used. Four experiments were carried out; two of them were pots trails in greenhouse and the other two were field trails in west Nubariya region throughout seasons of 2009/2010 and 2010/2011. Considering the tested sugarbeet varieties for susceptibility to $M$. incognita, all the cultivars according to Canto-Saenz's host suitability, can be distinguished to three categories, as responded to $M$. incognita, the first seriously affected and involved Alexa, Gazella, Panther and Sofie as susceptible ones, the second included reasonably affected varieties (Farida, Pamela, Pleno, Top and Toro) as Tolerant ones and the third as severely affected with nematode represented by Helios variety as Hypersusceptible one. In field Conditions experiment, studied parameters were; germination percentage, leaf weight, beet root yield, number of beets per feddan, TSS\%, pol\%, sugar recovery \% and sugar yield. Data of this part of study cleared that germination percentage, Leaf weight $\mathrm{t}_{\text {fed }}{ }^{-1}$, Number of roots and root yield $t$ fed $^{-1}$ with average values of $78.3 \%, 14.3,31.0$ and 27.0, respectively.

This paper as well seeks to study the yield response of high yielding sugarbeet varieties to different levels of Nemacur (Fenamiphos) input (T: No nematicide or Control; T1: Rate applied once at planting; T2: 50\% applied at planting $+\mathbf{5 0 \%}$ at 45 day After Planting) on root-knot nematodes under field conditions as percentage of avoidable loss. The maximum protection treatment rate applied once at planting (T1) was established to be most effective in reducing the damage caused by root-knot nematode comparison with treatment of $50 \%$ applied at planting $+50 \%$ at 45 day After Planting (T2). it can be concluded that sugarbeet varieties that categorized previously as susceptible had the highest avoidable loss \% due $\mathrm{T} 1$ and/or $\mathrm{T} 2$ for both roots and sugar yields, where sugarbeet varieties that categorized as tolerant had avoidable loss\% less than susceptible ones, also, in roots yield avoidable loss \% was greater than in sugar yield. This suggesting that sugarbeet varieties that categorized as tolerant were the best genotype with highest beet root

\footnotetext{
${ }^{1}$ Sugar Crops diseases \& Pests, Department Sugar Crops Research Institute, Agricultural Research Center (ARC), 12619, Giza, Egypt

${ }^{2}$ Genetic and Breeding, Department, Sugar Croup Research Institute, Agriculture Research Center (ARC), 12619, Giza,, Egypt.

${ }^{3}$ Physiology and Chemistry, Department, Sugar Crops Research Institute, Agriculture Research Center (ARC), 12619, Giza,, Egypt. Received March 14, 2013, Accepted March31, 2013
}

Keywords: Nubariya -sugarbeet varieties- Tolerancesusceptibility- Meloidogyne- sugar yield- FenamiphosTSS\%- sugar recovery\%- Field Conditions- pots trailsBeta Vulgaris.

\section{INTRODUCTION}

Sugarbeet (Beta vulgaris L.) growers face many production decisions with one of the most critical being variety selection. Sugarbeet varieties are chosen based on yield potential, cost, disease resistance, herbicide tolerance, and emergence potential. Without a uniform plant population throughout the field or region, growers will have difficulty maximizing sucrose yields (Smith $e t$ al., 2001). A uniform sugarbeet population minimizes variability in yield and sugar content of individual sugarbeet plants. The root knot nematodes are included within the genus Meloidogyne Goldi, and belong to a relatively small but important polyphagous group of highly adapted obligate plant pathogens. Typically, they are distributed worldwide and parasitize nearly every species of higher plant. Due to their endoparasitic way of living and feeding, root knot nematodes disrupt the physiology of the plant and may reduce crop yield and product quality and, therefore, are of great economic importance and make control necessary. Among strategies for control this pathogen is attempt to utilizing features may arise in the cultivated varieties of sugarbeet like resistance and/or tolerance to integrate with other control measures i.e. agricultural practice, rotation and safe chemical applications.

Resistance to root-knot nematode is rare; nematode feeding stimulated formation of giant cells in host tissues, resulting in root galls and protuberances, thus hindering sugar beet growth and limiting production (Yu, 2003). Therefore, it is obvious that many control measure modifications and development of new tools for crop health management are needed to maintain present levels of crop production as well as increase overall yields in this ever changing world. No sugar beet 
varieties are available in the infested sugar beet grown area with a high level of resistance to Meloidogyne spp., and some varieties are featured in some work with a moderate level of resistance. All other available varieties are believed to be susceptible to Meloidogyne spp., but their levels of tolerance have not been quantified. If sugar beet nematode tolerant varieties can be identified, then they could be grown to help minimize yield losses.

Sugar beet varieties differ in yield potential and qualities. Some of the observed differences in sugar yield, T.S.S. \%, sucrose $\%$ and purity $\%$ among varieties may have been the result of differences in yield potential among cultivars (Stevens et al. 2008 Tsialtas and Maslaris, 2012), whereas, others may have been the result of different levels of resistance to the root-knot nematode (Maareg et al., 2005; Gohar and Maareg, 2009; Saleh et. al., 2009 and EL-Sayed et al., 2009).

Therefore, this work was conducted to find out the level of susceptibility of sugarbeet varieties to Meloidogyne incognita, thus, most of its cultivation is done on marginal lands and low yields realized in Egypt. Also to determine the combined effect of Meloidogyne incognita on the growth and yield components of different varieties used. This paper as well seeks to study the yield response of high yielding sugarbeet varieties to different levels of Nemacur (Fenamiphos) input on root-knot nematodes under field conditions as percentage of avoidable loss.

\section{MATERIALS AND METHODS}

\section{a- Host Suitability of sugarbeet varieties for root- knot nematode, Meloidogyne incognita: (Greenhouse research)}

Ten varieties of sugarbeet (Beta Vulgaris Saccharifera) were kindly obtained form Sugar Crops Research Institute (SCRI) and used. Sandy loam soil collected from sugarbeet fields of West Nubariya province was air-dried, homogenized and steam sterilized using an autoclave for $3 \mathrm{~h}$ at $85^{\circ} \mathrm{C}$. Pots $(20$ $\mathrm{cm}$ diameter) were filled with soil $(3.5 \mathrm{~kg})$. Two Sugarbeet seeds of each variety were planted in each pot. The plants growing were placed on screen house bench in experimental design as a randomized complete block with a strip-pots arrangement of treatments with four replications. The horizontal factor was sugar beet varieties and vertical factor was nematode inoculation treatment (inoculated or free of Inoculum). Sugarbeet varieties are all multigerm, Alexa, Farida, Gazella, Helios, Pamela, Panther, Pleno, Sofie, Top and Toro. Two weeks old well established and healthy seedlings of sugarbeet varieties were thinned to one plant per pot before inoculation.
Nematode eggs were collected from the heavily infected roots of eggplant (Solanum melongena, 'Black beauty'). The eggplant plants were up-rooted and the egg masses were picked as described by Hartman and Sasser (1985). One hour before inoculation, Nematode inoculums' of $4000 \mathrm{M}$. incognita eggs per pot according to Gohar and Maareg (2009) - approximately 400 eggs $250 \mathrm{~cm}^{-3}$ soils. Inoculum was distributed into two holes (approximately $2.5 \mathrm{~cm}$ deep) and covered with soil. Pots were watered immediately following inoculation. The plants were then watered regularly and $15 \mathrm{~g}$ of compound fertilizer $(15: 15: 15)$ was added to the 3 weeks old plants.

Sixty days after sowing, the plants were up-rooted by placing the small pots in a slanting position into a big pan containing water, while being shaken gently until the soil was moved into the pan and roots were cleaned. The roots were examined and rated for galling responses on a scale; $1=1-2$ galls; $2=3-10$ galls; $3=11-20$ galls; $4=31100$ galls; $5=101$ galls and above according to Taylor and Sasser (1978). Before up rooting the plants, $250 \mathrm{~cm} 3$ of soil around each plant was collected up to a depth of $10-15 \mathrm{~cm}$. From each of the soil samples using a modified Bearman's tray method as described by Barker (1985), second juvenile larvae (J2) were extracted. From $2 \mathrm{~mL}$ aliquots of each extracts, $\mathrm{J} 2$ were counted under a dissecting microscope and this was repeated 10 times $(20 \mathrm{~mL})$ to estimate its population in $250 \mathrm{~cm}-3$ of soils.

The host efficiency (reproduction factor ' $R$ ') was calculated, where ' $\mathrm{R}$ ' $=\mathrm{Pf} / \mathrm{Pi}$, with $\mathrm{Pf}$ being final population in $250 \mathrm{~cm} 3$ of soil and Pi being the original inoculums. An 'R-factor' of less than or equal to one (1) indicates no apparent increase in the nematode population (Nwauzor, 1998). Final assessment of the various cultivars was based on Canto-Saenz's host resistance designations scheme as given in Table I. Growth characteristics of sugar beet seedlings were determined in different treatments by transferring them cleaned to the laboratory. In the laboratory, different growth factors including seedling height, seedling fresh weight; seedling dry weight, root length and root weight were measured by following common procedures (Tennant, 1975; Molla et al., 2001). The entire experiment was repeated one time under similar conditions.

\section{b- Quantitative and qualitative reaction of tested sugarbeet varieties to field infestation by $M$. incognita treated with Nemacur (Fenamiphos): (Field research)}

The field experiments were conducted for two autumn seasons of 2009/2010 \& 2010/2011 at Nubassed sector Drainage No. 6 in West Nubariya district, Egypt, 
Nubariya is located in the western desert to the west of the Nile Delta. Region represented here is located at $30^{\circ}$ $47^{\prime}$ north and $30^{\circ} 25^{\prime}$ east. Parent material is Pleistocene sandy deposits of the deltaic stage of river terraces. The area has been put under reclamation and agriculture in the recent few decades. A Variety of crops are grown in the area; field crops, such as sugarbeet, wheat, barley and maize, a wide variety of vegetables and fruits as well as citrus and fruit trees orchards. Depth of water table ranges between 6-8 m. Average annual air temperature approximately $20.0^{\circ} \mathrm{C}$ and average annual rainfall is about $23.0 \mathrm{~mm}$. The taxonomic name of the soil is typic quartzipsamments El- Khodre and Bedaiwy (2008). Four horizons can be distinguished in a typical profile. The soil of the field was non-saline-nonsodic, alkaline in reaction and had low organic matter (OM), phosphorus (P) and nitrogen $(\mathrm{N})$ contents. The physicochemical properties of experimental site are given in the Table 1

The two experimental plots were naturally infested with Meloidogyne incognita. The identity of $M$. incognita was confirmed using perineal patterns, as described by Eisenback et al. (1981).

The experiment was a $10 \times 3$ factorial arrangement of treatments. There were ten sugar beet varieties in these experiments, including all ten varieties previously used in pots experiments. The three times of nematicide applications were; T: No nematicide or Control; T1: Rate applied once at planting; T2: 50\% applied at planting $+50 \%$ at 45 day After Planting (DAP). The 30 treatments obtained were arranged in Randomized Complete Block Design and replicated 4 times. Experimental plots were six rows $(50 \mathrm{~cm}$ spacing $)$ by $3.5 \mathrm{~m}$ in length $\left(3 \mathrm{~m} \times 3.5 \mathrm{~m}=10.5 \mathrm{~m}^{2}\right.$ i.e. $\left.1 / 400 \mathrm{Fed}\right)$, Then manual sowing of seed of sugar beet varieties was carried out on one side of the ridges keeping hill to hill distance of about $20 \mathrm{~cm}$ according to layout plan to obtain a rate of 40000 plants fed. ${ }^{-1}$. All recommended agronomic and cultural practices including weeding, fertilization, irrigation and plant protection measures were followed during the entire course of study on a standardized uniform pattern for all the plots.

Fenamiphos as active ingredient is organophosphate chemical class. Nemacur used in this study is Granular (10G) i.e. $10 \%$ active ingredients, was applied at planting in the seed furrow at $1.5 \mathrm{~kg}$ a.i. per feddan this rate was determined according to Maareg et al. (1999) as an efficient rate fed $^{-1}$. Nemacur offers contact activity and works by interfering with the nervous system of the pest. This results in quick knockdown of nematodes. Systemic and contact poison against the major genera of nematodes attacking field crops, vegetables and turf with high nematicidal activity which can be applied broadcast, in-the-row, in band, by drench, before or at planting time, or to established plants. Complete soil incorporation is not essential Harding (1980). The experiment was harvested in the 1st week of May in both studied seasons.

Data regarding germination percentage, beet weight, beet yield, and Brix and sucrose contents (Pol $\%)$ along with sugar recovery were collected. Germination was recorded thirty days after planting, while beet weight, beet and leaf yield were recorded at the time of harvest. Then ten sugar beets were collected for quality analysis. The samples were washed with water, de-moisted and nematode gall indexing plus reproductive factor were done as described previously then subsamples sent to Nile Sugar Company Lab to determine technological characters as cut into slices. The slices were crushed in the juice extractor and juice was obtained and quantity was measured. The juice was filtered and filtrate consisted of all soluble solids including sucrose. The total soluble solids in the extract (Brix) were measured with the help of refractometer and sucrose contents (Pol \%) were measured with the help of Polarometer. Then the sugar recovery $(\%)$ in different sugar beet varieties was estimated with the help of formula:

Sugar Recovery $(\%)=[3 \mathrm{P} / 2\{1-(\mathrm{F}+5) / 100\}-\mathrm{B} / 2\{1-$ $(\mathrm{F}+3) / 100\}] \times 0.93$ (Anonymous, 1970), where

$\mathrm{P}=\mathrm{Pol} \%$ of juice.

$\mathrm{B}=\mathrm{T} . \mathrm{S} . \mathrm{S} \%$ of juice.

$\mathrm{F}=$ Fibre $\%$ beet.

$0.93=$ Recover factor.

The avoidable loss has been calculated by adopting the formula adopted by Jagdishwar Reddy (2001). as given below:

$$
\mathrm{Y}-\mathrm{Y} 1
$$

Avoidable loss $(\%)=\overline{\mathrm{Y}} \times 100$

Where,

$\mathrm{Y}=$ Mean yield in sprayed plot

$\mathrm{Y} 1=$ Mean yield in unsprayed plot $]$

The data collected were subjected to statistical analysis and means were compared with LSD test $(\mathrm{P}=$ 0.05 ) as described by Steel and Torrie (1980). 
Table 1. Soil analysis of the experimental sites over the two studied seasons

\begin{tabular}{lcc}
\hline Characteristic & Unit & Value \\
\hline Soil texture & -- & Loamy sand \\
\hline $\mathrm{EC}$ & $\mathrm{dS} \mathrm{m}^{-1}$ & 0.86 \\
\hline $\mathrm{pH}$ & -- & 8.01 \\
\hline Organic Matter & $\%$ & 0.67 \\
\hline $\mathrm{P}$ & $\mathrm{mg} \mathrm{kg}^{-1}$ & 5.10 \\
\hline $\mathrm{K}$ & $\mathrm{mg} \mathrm{kg}^{-1}$ & 89.00 \\
\hline $\mathrm{NO} 3-\mathrm{N}$ & $\mathrm{mg} \mathrm{kg}^{-1}$ & 0.31 \\
\hline
\end{tabular}

Table 2.Quantitative scheme for assignment of Canto - Saenz's host suitability (resistance) Designations

\begin{tabular}{lcl}
\hline $\begin{array}{c}\text { Plant Damage } \\
\text { Gall index) }^{\mathbf{y}}\end{array}$ & $\begin{array}{c}\text { Host efficiency } \\
\text { (R-factor) }^{\mathbf{z}}\end{array}$ & $\begin{array}{c}\text { Degree of resistance } \\
\text { (DR) }\end{array}$ \\
\hline$\leq 2$ & $\leq 1$ & Resistant \\
\hline$\leq 2$ & $>1$ & Tolerant \\
\hline$>2$ & $\leq 1$ & Hypersusceptible \\
\hline$>2$ & $>1$ & Susceptible \\
\hline
\end{tabular}

${ }^{\mathrm{Z}}$ reproductive factor: $\mathrm{R}=\mathrm{Pf} / \mathrm{Pi}$ where $\mathrm{Pi}=$ initial population density and $\mathrm{Pf}=$ final population density, ${ }^{\mathrm{Y}} \mathrm{Gall}$ index: $0=$ no gall formation; 5 = heavy gall formation source: Sasser et al (1984).

\section{RESULTS AND DISCUSSIONS}

\section{Greenhouse research:}

Table 3 indicates the different growth factors of ten sugarbeet varieties including seedling height, seedling fresh weight; seedling dry weight, root length and root weight as measured after 60 growing days under greenhouse conditions in pots inoculated and /or unincoulated with Meloidogyne incognita eggs.

The effects of $M$. incognita on the above mentioned sugarbeet seedlings growth factors were the most awful on seedling dry weight recording the highest reduction percentage $(89.8 \%)$ followed by seedling fresh (wet) weight $(80.0 \%)$, height $(75.7 \%)$, root length $(57.3 \%)$ and root weight $(54.3 \%)$. In regard of varieties $\times M$. incognita nematode interactions on growth factors as seedling root length, the tested varieties can be categorized by significant difference $(\mathrm{P}<0.05)$ to three levels, the first one implied slightly affected ones; the reduction\% didn't exceed $7.7 \%$, that was for sugarbeet varieties Farida, Pamela, Pleno, Top and Toro without significance among them, where the second level involved considerable reduction $\%$ around $32 \%$, that was for Alexa, Gazella, panther and Sofie, whereas, the third level was occupied by one sugarbeet variety (Helios) as suffered from severe reduction\% in root length estimated by $57.3 \%$.

Helios variety was the worst affected by variety $x$ $M$. incognita nematode interactions for seedling root weight recording $54.3 \%$ reduction followed by Alexa variety $(45.0 \%)$, where the least affected were Toro and
Farida varieties recording reductions of 14.0 and $19.0 \%$, respectively. the other seven tested sugarbeet varieties i.e. Gazella, Pamela, Panther, Sofie and Top recorded significant reduction\% ranged from 20.7 to $35.5 \%$ and couldn't be grouped in spite of noticeable difference among them. Seedlings height were also significantly ( $P$ $<0.05$ ) as affected by varieties $\times M$. incognita nematode interactions and can be distinguished to three categories, the first involves Farida, Pamela, Pleno, Top and Toro varieties as the least affected recording reduction\% ranged from 5.4 to $11.8 \%$, while the second one implied Alexa, Gazella, Panther and Sofie verities that recorded considerable height reduction $\%$ around $47.0 \%$, whereas, the third category occupied by the most affected variety (Helios) had a severe reduction\% (75.7\%) .

In regard to seedlings wet weight as influenced by $M$. incognita nematode inoculation, the ten tested sugarbeet varieties could be distinguished to two groups, the first one containing the least affect sugarbeet varieties i.e. Farida, Pamela, Pleno, Top and Toro that had reduction\% ranged from 7.1 to $13.3 \%$, and the second one implied the rest of varieties with severe reduction $\%$ in wet weight ranged from 65.5 up to 80.0 $\%$. The dry weight was the most affected growth factor by varieties $\times M$. incognita nematode interactions as declared previously and could be grouped to three categories, the first including the slightly affected varieties, Farida, Pamela and Pleno (with range from 5.3- 9.9\% reduction) and the second recording a considerable dry weight reduction $\%$ with 18.4 and $18.7 \%$ for Toro and Top varieties, respectively, while the third one implied the most severe reduction\% 
ranged from 79.8 to $89.8 \%$ for the rest sugarbeet tested varieties. There was significant difference $(\mathrm{P}<0.05)$ between the tested sugarbeet varieties when number of juveniles per $250 \mathrm{~cm}^{3}$ of soil and groups were considered i.e. there were varieties had more than 1000 J2 per $\mathrm{cm}^{3}$ (Gazella, Pamela, Panther and Toro), varieties had more than 900 and less than $1000 \mathrm{~J} 2$ per $\mathrm{cm}^{3}$ (Alexa, Farida, Pleno and Sofie) and varieties had less than $900 \mathrm{~J} 2$ per $\mathrm{cm}^{3}$ (Helios and Top).

Considering the tested sugarbeet varieties for susceptibility to $M$. incognita (Table 4 ) all the cultivars according to Canto-Saenz's host suitability (Sasser et al., 1984), can be distinguished to three categories, the first involves susceptible varieties i.e. Alexa, Gazella, Panther and Sofie that had root gall index ranged from 3.0 to 3.7 and $\mathrm{R}$ - factor ranged from 2.3 to 2.9 . The second category in this concern was due to those sugarbeet varieties with root gall indexing ranged from 1.7 to 2.0 and R- factor ranged 2.1 - 3.1 i.e. Farida, Pamela, Pleno, Top and Toro varieties. On the other hand, the third category holds only Helios variety with the highest root gall index (5.0) and lowest R- factor (0.7) i.e. the Hypersusceptible one.

Results in Table 3 in full consistency with those in Table 4, whereas, there are three categories for sugarbeet varieties as responded to $M$. incognita, the first seriously affected and involved Alexa, Gazella, Panther and Sofie as susceptible ones, the second

Table 3. Effect of root-knot nematodes, Meloidogyne incognita on the growth of sugarbeet (Beta Vulgaris Saccharifera) seedlings after 60 days of sowing in the greenhouse

\begin{tabular}{|c|c|c|c|c|c|c|c|c|c|c|c|c|}
\hline \multicolumn{2}{|c|}{$\begin{array}{l}\text { *Growth } \\
\text { Parameters }\end{array}$} & $\frac{\pi}{2}$ & 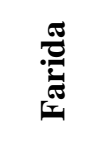 & 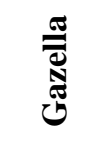 & 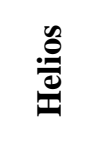 & ف류 & 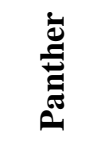 & $\frac{\stackrel{g}{0}}{2}$ & ڤू & $\stackrel{2}{\theta}$ & $\stackrel{\circ}{\theta}$ & $\begin{array}{c}\text { L.S.D } \\
\mathbf{0 . 0 5}\end{array}$ \\
\hline \multirow{3}{*}{ 흉 } & $* *$ Inc Free & 16.23 & 15.63 & 14.31 & 15.33 & 14.85 & 12.50 & 15.71 & 13.00 & 16.19 & 16.00 & 1.39 \\
\hline & Inc & 10.90 & 14.53 & 9.63 & 6.55 & 13.71 & 8.44 & 14.33 & 8.74 & 15.06 & 14.90 & 1.08 \\
\hline & Red \% & 32.8 & 7.0 & 32.7 & 57.3 & 7.7 & 32.5 & 8.8 & 32.8 & 7.0 & 6.9 & \\
\hline \multirow{3}{*}{ 造 } & Inc Free & 2.20 & 2.16 & 1.27 & 2.43 & 2.33 & 2.17 & 2.55 & 1.15 & 2.66 & 2.50 & 0.20 \\
\hline & Inc & 1.21 & 1.75 & 0.90 & 1.11 & 1.77 & 1.40 & 2.00 & 0.75 & 2.11 & 2.15 & 0.11 \\
\hline & Red \% & 45.0 & 19.0 & 29.1 & 54.3 & 24.0 & 35.5 & 21.6 & 34.8 & 20.7 & 14.0 & \\
\hline \multirow{3}{*}{ ज氖 } & Inc Free & 56.35 & 54.16 & 45.66 & 57.35 & 55.23 & 49.00 & 51.11 & 41.50 & 57.43 & 56.91 & 4.85 \\
\hline & Inc & 29.15 & 50.37 & 23.71 & 13.91 & 50.45 & 25.78 & 48.35 & 22.00 & 53.33 & 50.21 & 3.40 \\
\hline & Red \% & 48.3 & 7.0 & 48.1 & 75.7 & 8.7 & 47.4 & 5.4 & 47.0 & 7.1 & 11.8 & \\
\hline \multirow{3}{*}{$\sum_{\infty}^{30}$} & Inc Free & 24.81 & 23.23 & 23.50 & 19.27 & 21.19 & 27.19 & 24.52 & 18.17 & 24.55 & 23.89 & 2.13 \\
\hline & Inc & 5.10 & 21.58 & 8.11 & 3.85 & 19.19 & 7.46 & 21.25 & 5.10 & 21.84 & 21.00 & 1.35 \\
\hline & Red \% & 79.4 & 7.1 & 65.49 & 80.0 & 9.4 & 72.6 & 13.3 & 71.9 & 11.0 & 12.1 & \\
\hline \multirow{3}{*}{ 宓 } & Inc Free & 2.22 & 2.17 & 1.65 & 2.65 & 2.09 & 2.33 & 2.22 & 1.49 & 2.73 & 2.66 & 0.21 \\
\hline & Inc & 0.37 & 2.01 & 0.33 & 0.27 & 1.98 & 0.47 & 2.00 & 0.29 & 2.22 & 2.17 & 0.11 \\
\hline & Red \% & 83.3 & 7.4 & 80.0 & 89.8 & 5.3 & 79.8 & 9.9 & 80.5 & 18.7 & 18.4 & \\
\hline
\end{tabular}

*Growth parameters $=$ Root length $(\mathrm{SRL})(\mathrm{cm})$, root weight $(\mathrm{RW})(\mathrm{g})$, height $(\mathrm{SH})(\mathrm{cm})$, wet weight $(\mathrm{SWW})(\mathrm{g})$ and dry weight $(\mathrm{SDW})(\mathrm{g}) 60$ days after sowing in the greenhouse

** Inc Free $=$ Control with no inoculum, Inc $=$ Inoculated with nematode's eggs and Red $\%=$ reduction percent. included reasonably affected varieties (Farida, Pamela, Pleno, Top and Toro) as Tolerant ones and the third as severely affected with nematode represented by Helios variety as Hypersusceptible one. Kamel et al. (2011) reported that root-knot nematode significantly reduced sugarbeet plants shoot height, number of leaves, leaf area index, root length, root diameter and root weight, also, Maareg et al. (2009) in evaluation of certain sugarbeet varieties for their susceptibility to Meloidogyne javanica found that statistical differences among them in roots and leaves and indicated that some varieties like Pamela and Toro were not significantly in all assessed parameters they categorized Helios variety as a highly susceptible on the basis of damage index while, considered Pamela variety as moderately susceptible.

Under absent of biological stress of $M$. incognita nematode (in unincoulated pots), all ten tested varieties exhibited eventually significant differences $(P<0.05)$ in all assessed growth factors. This is consistent with findings of Dale et al. (2005) since they stated that comparisons is the fact that seed quality varies within varieties from seed lot to seed lot and year to year.

Differences in seed coatings, insecticide, and fungicide treatments, as well as environmental and harvest conditions during the year the seed is produced may affect seedling vigor and potential response. 
Table 4. Host Suitability of sugarbeet varieties (Beta Vulgaris Saccharifera) tested for rootknot nematode, $M$. incognita

\begin{tabular}{lllll}
\hline Sugarbeet varieties & Root all index* & \multicolumn{1}{c}{$\begin{array}{c}\text { J2/250 cm3 of } \\
\text { Soil }\end{array}$} & $\begin{array}{c}\text { R-factor host } \\
\text { efficiency** }\end{array}$ & Host status*** \\
\hline Alexa & 3.4 & 921 & 2.3 & Susceptible \\
\hline Farida & 1.7 & 959 & 2.4 & Tolerant \\
\hline Gazella & 3.7 & 1081 & 2.7 & Susceptible \\
\hline Helios & 5.0 & 281 & 0.7 & Hypersusceptible \\
\hline Pamela & 1.9 & 1243 & 3.1 & Tolerant \\
\hline Panther & 3.1 & 1162 & 2.9 & Susceptible \\
\hline Pleno & 2.0 & 922 & 2.3 & Tolerant \\
\hline Sofie & 3.0 & 960 & 2.7 & Susceptible \\
\hline Top & 1.9 & 842 & 2.1 & Tolerant \\
\hline Toro & 2.0 & 1159 & 2.9 & Tolerant \\
\hline Mean & 2.8 & 953 & 2.4 & \\
\hline LSD 0.05 & 1.1 & 386 & & \\
\hline
\end{tabular}

*Gall index: $0=$ no gall formation; $5=$ heavy gall formation.

**Reproduction factor: $\mathrm{R}=\mathrm{Pf} / \mathrm{Pi}$, where $\mathrm{Pi}$ =initial population density and $\mathrm{Pf}=$ final population density

**** Host status based on Canto-saenz host suitability designations

\section{Field Research:}

The results on average basis for germination percentage, leaf weight, beet root yield, number of beets per feddan, and sugar parameters such as TSS, pol\%, sugar recovery and sugar yield are summarized in Table 4. A significant difference $(\mathrm{P}<0.05)$ was recorded for germination percentage among varieties and/or among the three Nemacur (Fenamiphos); T0: No nematicide or Control; T1: Rate applied once at planting; T2: $50 \%$ applied at planting $+50 \%$ at 45 day After Planting (DAP). It is evident from the results that $\mathrm{T} 1$ showed maximum germination percentage, Leaf weight $\left(\mathrm{t} \mathrm{fed}^{-1}\right)$, No. of beets (' 000 ' $\left.\mathrm{fed}^{-1}\right)$ and beet yield $\left(\mathrm{t} \mathrm{fed}^{-1}\right)$ with average values of $78.3 \%, 14.3,31.0$ and 27.0 , respectively, While, regarding the maximum values for the same parameters of tested sugarbeet varieties under natural nematode infestation (T0) were due to Toro and Top which recorded 67.0 and $66.7 \%$ germination, respectively, while the minimum was recorded in Helios $(27.8 \%)$. Data at harvesting stage (Table 4) show that maximum leaf weight under infestation was noted also in Toro and Top (16.21 and $16.14 \mathrm{t} \mathrm{fed}^{-1}$, respectively), where the lowest was recorded by Helios $\left(4.04 \mathrm{t} \mathrm{fed}^{-1}\right)$. Maximum number of beets under infestation (T0) was recorded in Pamela (23.19 ' 000 ' $\mathrm{fed}^{-1}$ ) followed by Top and Toro (23.00 and 22.55 ' $000^{\prime}$ fed $^{-1}$, respectively) while Helios and Panther revealed low numbers of beets i.e., 7.27 and $9.45^{\circ} 000^{\prime}$ fed $^{-1}$ and minimum was noted in Mirabella (48.9 '000' ha-1).

Concerning studied nematode parameters under field condition i.e. gall index and reproductive factor, the lowest values were on T1 (Rate of Fenamiphos applied once at planting) whereas recorded 1.7 and 1.1, respectively. Regarding varieties responses under absent of Fenamiphos (T0), the lowest records for gall index ( $\leq$ 2) were due to sugarbeet varieties Farida, Pamela, Pleno, Top and Toro while the rest of the varieties (Alexa, Gazella, Helios, Panther and Sofie) recorded gall index $>2$. The same trend was observed on reproductive factor, whereas the lowest values $(\leq 2)$ were due to the same group of varieties and the highest (> 2) for the other group that achieved the highest in the previous parameter. Kamel et al. (2011) stated that Soil infection with nematode reduced the root weight of 28 varieties while increased root weight of some varieties was relative to control nematode. Root-knot nematode Meloidogyne javanica infected sugar beet C.V. Hilma and reduced leaves weight, plant height and root length (Maareg et al., 1999).

Regarding sugar contents, there was no significant difference $(\mathrm{P}<0.05)$ found among varieties for T.S.S, Pol and sugar recovery (Table 6). A maximum T.S.S percentage under T0 was observed in Toro $(21.93 \%)$ followed by Alexa and Top (21.33 and 21.14\%, respectively), while minimum in Helios (18.43\%). Concerning POL percent in sugar beet extract, variety Pleno equals with Top and had the highest POL percentage $(16.63 \%)$, while, minimum was recorded in Helios (13.65\%). Also, under natural nematode infestation, the maximum sugar recovery was observed in Farida variety $(12.0 \%)$ trailed by Top variety $(11.60 \%)$ whereas sugar beet variety Helios attained the lowest sugar recovery $(10.00 \%)$. The highest sugar yield under natural infestation (T0) was recorded in case of beet variety Pamela $\left(2.93 \mathrm{t} \mathrm{fed}^{-1}\right)$ followed by Top $(2.83$ 
$\left.\mathrm{t} \mathrm{fed}^{-1}\right)$, while lowest was recorded in Helios $\left(0.85 \mathrm{t} \mathrm{fed}^{-}\right.$ ${ }^{1}$ ) Table 6).

Fenamiphos (Nemacur) treatment of T1: Rate applied once (1.5 a.i. $\mathrm{kg} \mathrm{fed}^{-1}$ ) was the most efficient one for enhancing all qualitative performance except for T.S.S. that didn't show detectable change, but the others did, as POL percentage, sugar recovery $\%$ and sugar yield $\left(\mathrm{t} \mathrm{fed}^{-1}\right)$ recorded the highest values $(16.3 \%$, $12.10 \%$ and $3.1 \mathrm{t} \mathrm{fed}^{-1}$, respectively).

The sugarbeet yield differed with different varieties but it was comparable to the yields of previous investigations (Oad et al., 2001; Khan et al., 2004; Zahoor-ul-Haq et al., 2006). Ebrahimian et al. (2009) stated that there is a significant difference among sugarbeet cultivars for different parameters tested at different locations. Also, Ahmad et al. (2012) showed that significant differences were noted for number of beets among varieties and varieties differed in sugar contents.

Table 7 Illustrates the avoidable loss percentage in roots and sugar yields over control using Fenamiphos as

Table 5. Combined quantitative reaction of tested sugarbeet varieties to field infestation by $M$. incognita treated with Nemacur (Fenamiphos) over two successive seasons $(2009 / 2010$ \& 2010/2011)

\begin{tabular}{|c|c|c|c|c|c|c|c|c|c|c|c|c|c|}
\hline $\begin{array}{l}\text { Sugarbe } \\
\text { Vars. } \\
\text { Treatments } \\
\text { \& Reaction }\end{array}$ & & $\frac{\pi}{2}$ & 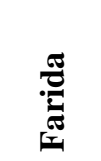 & 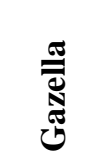 & 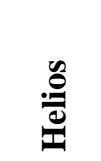 & 竞 & 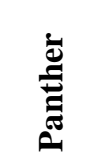 & 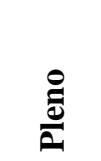 & 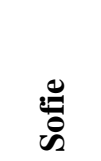 & $\stackrel{2}{\theta}$ & $\stackrel{0}{\theta}$ & Mean & $\begin{array}{l}\text { L.S.D } \\
0.05\end{array}$ \\
\hline \multirow{3}{*}{$\begin{array}{l}\text { Germination } \\
(\%)\end{array}$} & T0 & 43.7 & 56.1 & 39.7 & 27.8 & 61.3 & 40.3 & 63.3 & 35.6 & 66.7 & 67.0 & 50.2 & 5.14 \\
\hline & T1 & 68.5 & 81.3 & 77.9 & 65.4 & 84.3 & 73.0 & 85.3 & 71.6 & 88.3 & 87.7 & 78.3 & 7.89 \\
\hline & T2 & 44.1 & 66.7 & 44.3 & 40.0 & 67.2 & 42.7 & 77.0 & 40.3 & 71.7 & 70.3 & 56.4 & 5.82 \\
\hline \multirow{3}{*}{$\begin{array}{l}\text { Leaf weight } \\
\left(t_{\left.\text {fed }^{-1}\right)}\right.\end{array}$} & T0 & 6.44 & 11.72 & 5.18 & 4.04 & 14.83 & 5.26 & 12.52 & 4.73 & 16.14 & 16.21 & 9.7 & 1.00 \\
\hline & T1 & 10.15 & 16.98 & 10.17 & 9.50 & 19.39 & 9.53 & 16.88 & 9.52 & 19.36 & 21.21 & 14.3 & 1.49 \\
\hline & T2 & 6.53 & 13.93 & 6.00 & 5.80 & 16.26 & 5.78 & 15.23 & 5.36 & 17.35 & 17.01 & 10.9 & 1.14 \\
\hline \multirow{3}{*}{$\begin{array}{l}\text { No. of beets } \\
\left({ }^{6} 000{ }^{\prime} \text { fed }^{-1}\right)\end{array}$} & T0 & 17.5 & 22.4 & 15.9 & 11.1 & 24.5 & 16.1 & 25.3 & 14.2 & 26.7 & 26.8 & 20.1 & 2.05 \\
\hline & T1 & 27.4 & 32.5 & 31.2 & 22.6 & 33.7 & 29.2 & 34.1 & 28.6 & 35.3 & 35.1 & 31.0 & 3.15 \\
\hline & T2 & 17.6 & 26.7 & 17.7 & 16.0 & 26.9 & 17.1 & 30.8 & 16.1 & 28.7 & 28.1 & 22.6 & 2.33 \\
\hline \multirow{3}{*}{$\begin{array}{l}\text { Beet yield } \\
\left(\text { t fed }^{-1}\right)\end{array}$} & T0 & 12.00 & 20.13 & 10.00 & 7.27 & 23.19 & 9.45 & 22.00 & 8.17 & 23.00 & 22.55 & 15.8 & 1.64 \\
\hline & T1 & 25.12 & 34.15 & 18.31 & 17.53 & 35.84 & 18.23 & 33.12 & 18.18 & 34.85 & 35.15 & 27.0 & 2.81 \\
\hline & T2 & 14.45 & 24.38 & 10.81 & 8.11 & 25.68 & 10.50 & 26.11 & 11.78 & 25.80 & 26.00 & 18.4 & 1.92 \\
\hline \multirow{3}{*}{$\begin{array}{l}\text { Gall } \\
\text { index }\end{array}$} & T0 & 3.4 & 2.0 & 3.7 & 4.9 & 1.9 & 3.2 & 1.7 & 3.7 & 1.7 & 1.9 & 2.8 & 0.28 \\
\hline & T1 & 1.7 & 1.1 & 2.0 & 2.6 & 1.0 & 2.3 & 1.3 & 2.7 & 1.2 & 1.3 & 1.7 & 0.17 \\
\hline & T2 & 2.3 & 1.6 & 2.7 & 3.5 & 1.5 & 3.0 & 1.7 & 3.3 & 1.5 & 1.7 & 2.3 & 0.22 \\
\hline \multirow{3}{*}{$\begin{array}{l}\text { Reproductive } \\
\text { factor }\end{array}$} & T0 & 2.65 & 1.59 & 2.94 & 3.89 & 1.55 & 3.00 & 1.33 & 3.33 & 1.55 & 1.33 & 2.3 & 0.23 \\
\hline & T1 & 1.35 & 0.81 & 1.50 & 1.89 & 0.79 & 1.55 & 0.55 & 1.65 & 0.65 & 0.63 & 1.1 & 0.11 \\
\hline & T2 & 2.33 & 1.33 & 2.55 & 3.37 & 1.11 & 2.65 & 1.00 & 2.65 & 1.11 & 1.33 & 1.9 & 0.19 \\
\hline \multicolumn{2}{|c|}{$\begin{array}{l}\text { Rank on T1 for } \\
\text { beet(roots) yield }\end{array}$} & 6 & 4 & 7 & 10 & 1 & 8 & 5 & 9 & 3 & 2 & & \\
\hline
\end{tabular}

T0: No nematicide or Control; T1: Rate applied once at planting; T2: 50\% applied at planting + $50 \%$ at 45 days After Planting (DAP).

Average Pi for Root-knot nematode across the two studied seasons was 196 juvenile $/ 250 \mathrm{~cm}^{3}$ soils
T1: Rate applied once at planting and T2: 50\% applied at planting $+50 \%$ at 45 day After Planting (DAP) was also calculated by obtaining yield from nematicide treatments and untreated plots. The avoidable loss has been calculated by adopting the formula adopted by Jagdishwar Reddy (2001) as given on materials and methods. It is evident from the data presented in Table 7 that the percentage of avoidable loss was greater in $\mathrm{T} 1$ than $\mathrm{T} 2$ for both roots and sugar yield as their averages 43.9 and $34.8 \%$ of roots yield due to $\mathrm{T} 1$ and $\mathrm{T} 2$, and 42.7 and $39.2 \%$ of sugar yield due to the same two treatments. However, T1 and T2 were superior to untreated control (T0).

From the same Table (7), it can be concluded that sugarbeet varieties that categorized previously as susceptible had the highest avoidable loss\% due $\mathrm{T} 1$ and/or T2 for in both roots and sugar yields, where sugarbeet varieties that categorized as had avoidable loss\% less than susceptible ones, also, in roots yield avoidable loss \% was greater than in sugar yield. 
Table 6. Combined qualitative reaction of tested sugarbeet varieties to field infestation by $M$. incognita treated with Nemacur (Fenamiphos) over two successive seasons $(2009 / 2010 \&$ 2010/2011)

\begin{tabular}{|c|c|c|c|c|c|c|c|c|c|c|c|c|c|}
\hline $\begin{array}{l}\text { Sugarl } \\
\text { Vars. } \\
\text { Treatments } \\
\text { \& Reactior }\end{array}$ & & $\frac{\pi}{2}$ & 莺 & שู & & 部 & 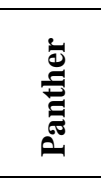 & $\frac{O}{0}$ & ڤั & $\stackrel{0}{\theta}$ & $\stackrel{0}{0}$ & mean & $\begin{array}{l}\text { LSD } \\
0.05\end{array}$ \\
\hline \multirow{3}{*}{ T.S.S (\%) } & T0 & 21.33 & 19.13 & 19.45 & 18.43 & 19.31 & 20.13 & 20.17 & 18.86 & 21.14 & 21.93 & 20.0 & 1.84 \\
\hline & T1 & 21.13 & 19.00 & 19.28 & 18.18 & 19.03 & 19.19 & 20.13 & 18.53 & 21.21 & 21.73 & 19.7 & 1.82 \\
\hline & T2 & 21.23 & 19.25 & 19.30 & 18.27 & 19.17 & 20.02 & 20.15 & 18.66 & 21.14 & 22.19 & 19.9 & 1.79 \\
\hline \multirow{3}{*}{ Pol (\%) } & T0 & 16.23 & 16.23 & 14.23 & 13.65 & 15.91 & 14.52 & 16.63 & 15.98 & 16.63 & 16.36 & 15.6 & 1.83 \\
\hline & T1 & 17.21 & 16.56 & 14.00 & 14.00 & 16.12 & 17.67 & 17.00 & 16.54 & 16.50 & 17.32 & 16.3 & 1.87 \\
\hline & T2 & 16.73 & 16.00 & 13.98 & 15.36 & 15.80 & 16.93 & 16.59 & 16.33 & 14.73 & 15.21 & 15.8 & 1.81 \\
\hline \multirow{3}{*}{$\begin{array}{l}\text { Sugar } \\
\text { Recovery } \\
(\%)\end{array}$} & T0 & 10.40 & 12.00 & 10.30 & 10.00 & 11.00 & 10.80 & 10.40 & 11.20 & 11.20 & 11.60 & 10.9 & 1.25 \\
\hline & T1 & 10.60 & 11.60 & 10.80 & 10.60 & 12.60 & 11.00 & 12.00 & 12.00 & 11.90 & 12.10 & 11.5 & 1.32 \\
\hline & T2 & 11.00 & 11.30 & 11.00 & 10.40 & 11.90 & 11.00 & 11.80 & 11.60 & 11.30 & 11.80 & 11.3 & 1.30 \\
\hline \multirow{3}{*}{$\begin{array}{l}\text { Sugar } \\
\text { Yield } \\
\left(t \text { fed }^{-1}\right)\end{array}$} & T0 & 1.41 & 2.36 & 1.17 & 0.85 & 2.93 & 1.11 & 2.58 & 0.96 & 2.83 & 2.34 & 1.9 & 0.21 \\
\hline & T1 & 2.95 & 4.00 & 2.15 & 2.06 & 4.53 & 2.14 & 3.88 & 2.13 & 3.62 & 3.65 & 3.1 & 0.36 \\
\hline & T2 & 1.69 & 2.86 & 1.27 & 0.95 & 3.25 & 1.23 & 3.06 & 1.38 & 2.68 & 3.05 & 2.1 & 0.25 \\
\hline \multicolumn{2}{|c|}{$\begin{array}{l}\text { Rank on T1 for } \\
\text { sugar yield }\end{array}$} & 6 & 2 & 7 & 10 & 1 & 8 & 3 & 9 & 5 & 4 & & \\
\hline
\end{tabular}

Table 7. Combined reaction as percentage of avoidable loss of tested sugarbeet varieties to field infestation by $M$. incognita treated with Nemacur (Fenamiphos) over two successive seasons $(2009 / 2010 \& 2010 / 2011)$

\begin{tabular}{lcccc}
\hline \multirow{2}{*}{ Sugarbeet varieties } & \multicolumn{4}{c}{ Percentage of avoidable loss } \\
\cline { 2 - 5 } & \multicolumn{3}{c}{ In roots yield } & In sugar yield \\
\cline { 2 - 5 } & $\mathbf{T 1}$ & 42.48 & 52.20 & T2 \\
\hline Alexa & 52.23 & 28.61 & 41.00 & 42.71 \\
\hline Farida & 41.05 & 40.96 & 45.58 & 88.50 \\
\hline Gazella & 45.39 & 53.74 & 58.74 & 53.88 \\
\hline Helios & 58.53 & 28.35 & 35.32 & 28.26 \\
\hline Pamela & 35.30 & 42.40 & 48.13 & 42.52 \\
\hline Panther & 48.16 & 21.17 & 33.51 & 21.13 \\
\hline Pleno & 33.57 & 35.20 & 54.93 & 35.21 \\
\hline Sofie & 55.06 & 28.84 & 21.82 & 25.97 \\
\hline Top & 34.00 & 26.03 & 35.89 & 25.97 \\
\hline Toro & 35.85 & 34.8 & 42.7 & 39.2 \\
\hline Mean & 43.9 & 3.45 & 4.27 & 3.86 \\
\hline LSD0.05 & 4.38 & $50 \%$ & \\
\hline : Non
\end{tabular}

T0: No nematicide or Control; T1: Rate applied once at planting; T2: 50\% applied at planting + $50 \%$ at 45 days After Planting (DAP).

Gohar et al. (2012a) evaluated a collection of $M$. javanica susceptible sugarbeet varieties for differing levels of yield decline (tolerance), their tolerance to parasitism by this nematode. If nematode tolerant (low yield decline) but susceptible (high nematode reproduction) sugar beet varieties can be identified, they could be grown rather than intolerant varieties to reduce yield loss. The yield potential and percentage yield loss to $M$. javanica were measured in 15 sugar beet varieties by comparing yields in Dazomet $98 \%$ (Methyl Isothiocyanate) - fumigated and nonfumigated plots. Also, Gohar et al (2012b) in other investigation that the overall mean of increase percentage in root yield ton/ feddan for Ethoprop treated plot was about $51 \%$. The highest value of sugar yield (3.993 tons/ feddan) was for Lola variety and the lowest went to Baraka variety (0.958 tons/ feddan). 


\section{CONCLUSION}

-In conclusion, sugarbeet varieties that categorized as tolerant were the best genotype with highest beet root yield, sugar recovery and ultimately gave maximum sugar yield.

-All varieties exhibited stunted growth due to heavily infection on roots, However, other varieties of sugarbeet from different sources should be screened in order to get resistant or tolerant cultivars to get greater yield. It is also advisable not to plant the cultivars for several years on the field. This will avoid M. incognita build up to cause great yield loss.

-However, assessment of different rates of Fenamiphos (Nemacur) on root-knot nematode on sugarbeet varieties would help to determine further which rate of Nemacur are most effective against $M$. incognita and which are most beneficial to improving the technological quality of the roots. Assessment of application rates of Nemacur used in current study would help to establish optimum levels for yield improvement and nematode management.

-The maximum protection treatment rate applied once at planting (T1) was established to be most effective in reducing the damage caused by root-knot nematode comparison with treatment of 50\% applied at planting $+50 \%$ at 45 day After Planting (T2). The nematicide residues at harvest (PHI for Fenamiphos is 60 days) were below detectable level in $\mathrm{T} 1$; hence the maximum protection (T1) application schedule can be suggested to farmers.

-The work confirms the suppressive effects of Fenamiphos -a nematicide on root knot nematodes Meloidogyne species on sugarbeet crop which is well adapted to the stressful growing conditions of the Nubariya region and has excellent Technological qualities. And that without controlling the activities of root-knot nematode ( $M$. incognita), appreciable yield and income on sugarbeet cultivation will not be possible.

\section{RECOMMENDATION}

This study recommends carrying over susceptibility screening test against root-knot nematode, Meloidogyne incognita "sixty day's test" for sugarbeet varieties intend or likely be grown in areas contaminated with this nematode, through collaboration between sugar production companies and Sugar Crop Research Institute with the ability to conduct this type of tests to verify the resistant and/or at least tolerant variety (ies) for this pest, to be sown under IPM measures including applying appropriate nematicide achieved in this study, i.e. applied once at planting so as to achieve yield with good quality and quantity of sugarbeet roots.

\section{REFERENCES}

Ahamad S.,M. Z. N Iqbal, N. M. Cheema and K. Mahmood. 2012. Evaluation of Sugar Beet Hybrid Varieties under Thal-Kumbi Soil Series of Pakistan Int. J. Agric. Biol., Vol. 14, No. 4: 605-608

Anonymous, 1970. Laboratory Manual for Queensland Sugar Mills, $5^{\text {th }}$ edition. Division of Mill Technology, Bureau of Sugar Experiment Station, Brisbane, Queensland, Australia. Pp 150.

Barker, K.R., 1985. Nematode Extraction and Bioassays. In: Barker, K.R., C.C. Carter and J.N. Sasser (eds.), An Advanced Treatise on Meloidogyne, Vol. II Methodology, pp: 19-35. An Co-Op.

Dale T. M., J. M. McGrath, and K. A. Renner. 2005. Response of Sugarbeet Varieties and Populations to Postemergence Herbicides. Journal of Sugar Beet Research Vol. 42 Nos. 3 \& 4: 119-126.

Ebrahimian, H.R., S.Y. Sadegheian, M.R. Jahadakbar and Z. Abbasi, 2009. Study of daptability and stability of sugar beet monogerm cultivars in different locations of Iran. $J$. Sugar Beet, 24: 1-13.

Eisenback, J.D., H. Hirschmann, J.N. Sasser and A.C. Triantaphyllou, 1981. A guide to the four most common species of root-knot nematodes (Meloidogyne spp.) with a pictorial key. A cooperative publication of North Carolina State University and USAID, pp: 48.

EL- Khodre, A. and M. N. A Bedaiwy 2008. Experimental Characterization of Physio-chemical, Hydrodynamic and Mechanical Properties of Two Typical Egyptian Soils. Tishreen University Journal for Research and Scientific Studies- Biological Sciences Series Vol. (30) No. (5): 169-191.

EL-Sayed A.K; Saleh, M.S.; I.M.A. Gohar and Nancy A. Abo Ollo (2009). Isoperoxidase activity in root-knot nematode sugar beet resistance plants. Alex. Sci. Exch., Vol. 30, No. 2: $162-172$.

Gohar, I.M.A. and M.F. Maareg .2009. Effect of inoculum level, type, plant age and assessment date on evaluating sugar beet resistance methods for root-knot nematode, Meloidogyne incognita. J. Agric. Sci. Mansoura., 34 (5): 5401-5419.

Gohar, I.M.A; K.M. Agami and M. S. M Aly. 2012. Relationship between Yield Potential and Percentage Yield Decline Caused by the Root-knot Nematode, Meloidogyne javanica for some Sugar beet varieties sown in West Nubariya Region. J. Plant Production, Mansoura Univ. Vol. 3 (8): 2361 - 2374.

Gohar, I.M.A.; A.M. Abd El-razek; A.A. Abo El-Ftooh; M.M. Abd-El Rahmanand K.M. Agami. 2012. The influence of some sugarbeet varieties and nematicide Ethoprop (mocap) on the root-knot nematode- Fusarium disease complex at Ismailia and Nubariya regions. Minufiya J. Agric. Res. Vol.,37 No. (1): 1409-1427.

Harding, W.C. 1980. Pesticide profiles, part two: fungicides and nematicides. Univ. Maryland, Coop. Ext. Service Bull. No. 283, 22 pp. 
Hartman, K.M. and J.N. Sasser, 1985. Identification of Meloidogyne Species on the Basis of Differential Host Test and Perineal-Pattern Morphology, pp: 69-77.

Jagdishwar Reddy, D. 2006. Estimation of avoidable losses due pests of grapevine. Indian J. Agric. Res., 40 (4): $282-$ 285.

Kamel H.A., A.I. Abd El Fattah, W.M.A. El-Nagdi and D.I. H. El-Geddawy. 2011. Evaluation of some sugar beet varieties for Meloidogtne incognita resistance as induced by gamma-irradiation. Pak. J. Nematol., 29 (1): 93-109.

Khan, D., I. Khan, P. Khan and G. Rehman, 2004. Sugar beet cultivation in the southern parts of NWFP. Pakistan Sugar J., 19: 19-24.

Maareg M. F; A. El-Gindi; Mona, E. El-Shalaby and Abeer, S. Yassin. 2009. Evaluation of certain sugar beet varieties for their productivity and susceptibility to Root-knot nematode, Meloidogyne javanica. J. Agric. Sci. Mansoura., Vol. 34. (6): 6851-6861.

Maareg M. F; I. M.A. Gohar and A.M. Abdel Aal. 2005. Susceptibility of twenty one sugarbeet varieties to the root-knot nematode, Meloidogyne incognita at West Nubariya District. . Egypt. J. Agric. Res., 83 (2): 789- 801

Maareg, M.F., Badr, S.T. A. \& Oteifa, B. A. 1999. Effect of two city waste organic composts, Fenamiphos and ammonium nitrate on controlling Meloidogyne javanica and productivity of sugar beet. Egypt J. Agronematol., 3:95-113.

Molla, A. H., Shamsuddin, Z. D., Halimi, M. S., Morziah, M. and Puteh, A. B. 2001. Potential for enhancement of root growth and nodulation of soybean coinoculated with Azospirillum and Bradyrhizobium in laboratory systems. Soil Biology and Biochemistry, 33: 457-463.

Nwauzor, E.C., 1998. Screening Cassava (Manihot esculentum (rantz.) varieties for Resistance to Root-knot Nematode, Meloidogyne incognita, kofoid and white 1919

Oad, F.C., A. Hameed Ansari, B.K. Solangi, M.U. Khail, G.N. Sohu and N.L. Oad, 2001. Performance Evaluation of Exotic Sugar Beet under Selected Agro-Climatic Conditions of Sindh Province. Int. J. Agric. Biol., 4: 472474.
Saleh, M.S.; A.K. EL-Sayed; I.M.A. Gohar and Nancy A. Abo Ollo (2009). Evaluation of twenty seven sugar beet genotypes for resistance to root-knot nematode (Meloidogyne javanica). Alex. Sci. Exch., Vol. 30, No. 2: 289-298

Sasser, J.N., C.C. Carter and K.M. Hartman, 1984. Standardization of Host Suitability Studies and Reporting of Resistance to Root-knot Nematode, p: 7. Raleigh, N.C. U.S.A.

Smith, J. A., L. W. Panella, and C. D. Yonts. 2001. Seed and varieties. In R. G. Wilson, J. A. Smith and S. D. Miller (ed.) Sugarbeet production guide. Univ. of Nebraska Coop. Ext. EC01-156. P. 9-20.

Steel, R.G.D. and J.H. Torrie, 1980. Principles and Procedures of Statistics: A Biomaterical Approach. Mc Graw Hill Inc; New York, USA.

Stevens W. B.;R. D. Violett; S. A. Skalsky; and A.O. Mesbah. 2008. Response of Eight Sugarbeet Varieties to Increasing Nitrogen Application: I. Root, Sucrose, and Top Yield. Journal of Sugar Beet Research: 65- 83.

Taylor, A.L. and J.N. Sasser, 1978. Biology, Identification and Control of Root-knot Nematodes (Meloidogyne spp), p: 111. Co-op. Publication, Department of Plant Patholnorth Carolina state University and US Agency International Dev. Raleigh, N.C

Tennant, D. 1975. A test of a modified line intersects method of estimating root length. Journal of Ecology, 63:9951001.

Tsialtas J. T. and N. Maslaris (2012). Leaf physiological traits and its relation with sugar beet cultivar success in two contrasting environments. International Journal of Plant Production 6 (1), January 2012: 1735-6814.

YU, M. H. 2003. Development of Root-knot nematode resistant sugar beet varieties. $1^{\text {st }}$ joint IIRB-ASSBT Congress, 26"'Feb.-1 March 2003, San Antonio (USA) 763-765.

Zahoor-ul-Haq, A. Zeb and F. Mehmood, 2006. Yield and quality of two cultivars of sugar beet as influenced by fertilizer applications. Pakistan J. Sci. Industr. Res., 49: 211-214. 


\section{الملخص العربي}

\section{تحمل بعض اصناف بنجر السكر لنيماتودا تعقد الجذور (مليدوجين انكوجنيتا) وفاءة المبيد النيماتودي فينمافوس(نيماكور) للمكافحة تحت ظروف الحقل}

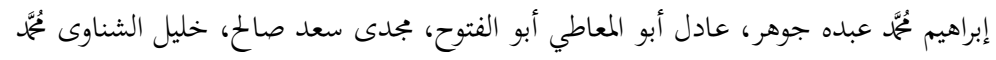

الزراعة وقياس الاستجابة على اساس قيمة النسبة المئوية للخسارة

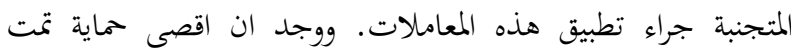
كانت في المعاملة ت1 1 التي قللت من ضرر نيماتودا تعقد الجذور. واستنتج من ذلك ان الاصناف التي صنفت سابقا على انا حساسة هي التي حققت عند هذه المعاملة اعلى قيمة لنسبة الحسارة المتجنبة وذلك بالنسبة لحاصل الجذور والسكر وكانت نسبة الخسارة المتجنبة في الجذور اكبر من تلك في السكر. وتوصي هذه الدراسة بان الاصناف التي تم تقسيمها على اساس اها متحملة, هي الاصناف الاكثر

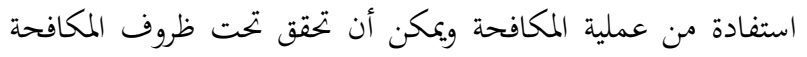

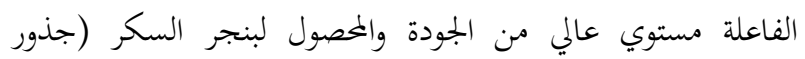

$$
\text { ونكر). }
$$

التوصية:

توصي هذه الدراسة بعمل اختبار الحساسية ضد نيماتودا تعقد

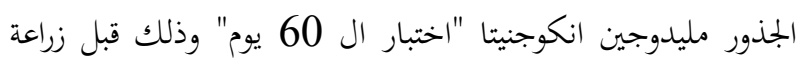
أصناف بنجر السكر المحتمل زراعتها في المناطق الملوثة بهذه النيماتودا

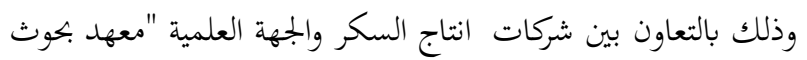
المحاصيل السكرية" ذات القدرة علي إجراء هذا النوع من الاختبارات

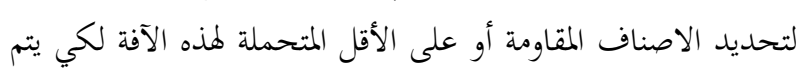

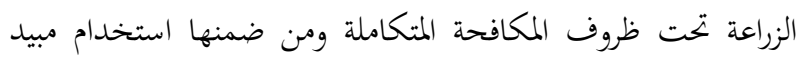
نيماتودي مناسب على النحو الذي تم التوصل إليه في هذه الدراسة،

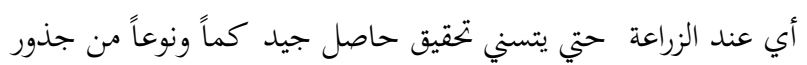
بنجر السكر.
لمعرفة مستوى حساسية أصناف معينة من بنجر السكر لنيماتودا

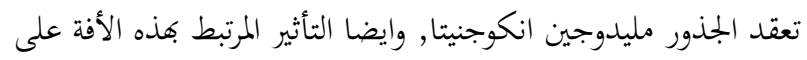

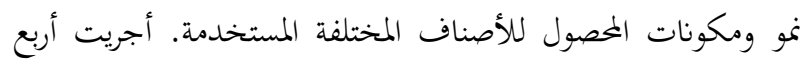

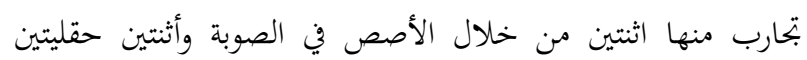

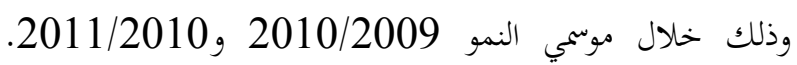

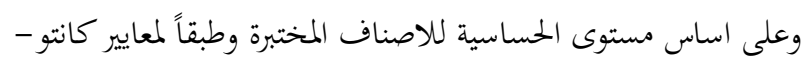

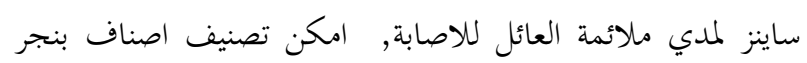
السكر المختبرة إلى ثلاث فئات, الاولي وهي القابلة للاصابة والتضرر بشدة اي (الحساسة) وتضمن الاصناف (الكسا وجازيلا وبانثر

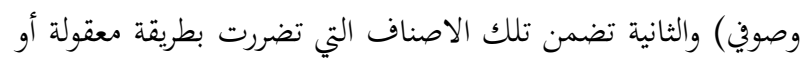

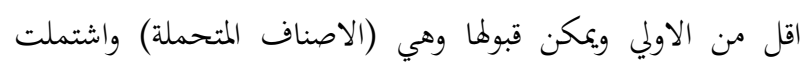

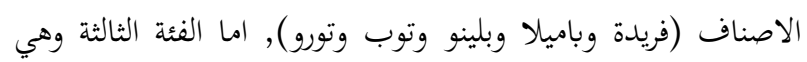

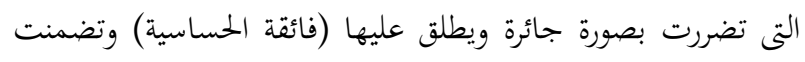
صنفاً واحداً وهو (هيليوس). (ما تحت ظروف الحقل, كانت المقاييس

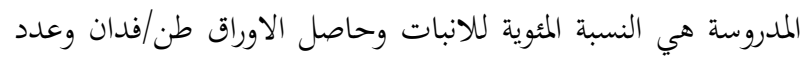
النباتات/فدان وكذلك حاصل الجذور طن/فدان وكان متوسطاتها في المعاملة الاكثر تفاعلاً مع الاصناف 78\% و 14.3و 31.0 و27.0 على التوالى

مدف هذه الدراسة ايضاً قياس الاستجابة المحصولية للاصنافة عالية المحصول والمنزرعة في الاراضي المصابة بالنيماتودا لطريقة تطبيق

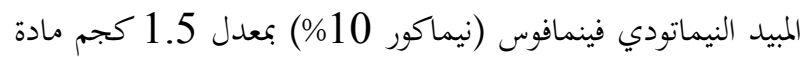
فعالة, ت 1 تطبيق الكمية دفعة واحدة عند الزراعة او ت2 2 وهي تطبيق 50\% من الجرعة عند الزراعة و50\% بعد 45 يوما من 